\title{
A Neo-liberal Exception? The Defence Industry 'Turkification' Project
}

\author{
Anouck Gabriela Côrte-réal Pinto
}

\begin{abstract}
Presented at once as an example, evidence, and even a condition of the economic, technological, political and security development of Turkey, the 'Turkification' of the defence industry lies at the heart of the government's legitimacy. Following a sociohistorical approach, this chapter aims to understand how this major project, inseparable from the ongoing formation of the state and of a national bourgeoisie organically related to it, was reconfigured in the neo-liberal era not despite globalisation but based on it, particularly through the commodification of Muslim solidarity and military protection. This project appears to constitute an instrument of 'nationaliberal' extraversion that is part of an unstable quest for hegemony, riven by numerous conflicts.
\end{abstract}

\section{Introduction}

The coming to power in Turkey in 2002 of the Justice and Development Party (Adalet ve Kalkinma Partisi, AKP), an offshoot of political Islam, is generally presented as the culmination of neo-liberal reforms in Turkey. These reforms, it is said, marked the end of the military-nationalist hegemony, as evidenced both by the large number of them that furthered the demilitarisation of the political scene and by the great mass trials of Turkish officers (the Ergenekon and Balyoz or 'Sledgehammer' cases). How, then, are we to interpret the reappropriation by this same party of the major project of the 'Turkification' of the defence industry, symbol of an enlightened pro-activism and a highly illiberal interventionism? The incantatory slogan 'a national tank, a national satellite and a national airline' ('Milli tank, milli uydu, milli uçak'), delivered during the 2011 elections and repeated and reinforced by the '2023 Political Vision of the AKP' (AK Parti 2023 Siyasi vizyonu), illustrates the particular commitment of the 'moderate Islamic' party to this major military project as a legitimising tool and a form of moral armament of the population (Sabah, 2011; AKP, 2012). This discursive focus is also reflected in an exceptional increase in military

(C) ANOUCK GABRIELA CÔRTE-RÉAL PINTO, 2017 | DOI 10.1163/9789004349551_013

This is an open access chapter distributed under the terms of the prevailing cC-BY-NC license at the time 89004349551 of publication. 
expenditure since 2006, partly due to the soaring number of major national defence projects initiated by the AKP: the 'hundred percent Turkish' Anka drone, the 'national' Altay tank, the 'local' Atak helicopter, the Göktürk satellite, and the MILGEM warship, etc. (Yentürk, 2014). Finally, it coincides with an unprecedented internationalisation of the armament sector, marked by a diversification of partners and external suppliers and by an exceptional rise in exports.

Following a socio-historical, 'non-dependentist approach to dependence' as proposed by Jean-François Bayart (Bayart, 2006, vi), an approach itself inspired by Gramsci, this chapter aims to understand how this major project of Turkification-inseparable from the ongoing formation of the Turkish state and a national bourgeoisie organically linked to it - has continued to develop in the neo-liberal era, not in spite of globalisation but based on it. In particular, we will focus on the interrelated levels of the project's sectoral, national, and international dimensions in order to understand how this development project is a fiction with multiple power effects; how it articulates, feeds into and results from a market logic and a logic of national affirmation. By highlighting the arts of 'making do' with globalisation (Certeau, 1990), this text calls into question both the proactive vision of the political and the vision of a self-regulating market; two ahistorical theories that are largely dominant in discourses regarding development in Turkey. ${ }^{1}$ With few exceptions, the concept of development is presented in Turkish scholarly literature either as a social engineering project (a Kemalist project or the Islamic project promoted by Necmettin Erbakan) or as an economic achievement; reflecting, respectively, a desire to break free from the past and a desire to enter into capitalist modernity (Unsaldi, 2011). By focusing on the historicity of this concept in Turkey through an analysis of the major project of the Turkification of the defence industry, we can illustrate and understand its hegemonic nature, its multiple meanings, and its concrete effects of domination.

2

\section{An Exception to the Neo-liberal Rule? The Genesis of an 'Anachronistic' Development Project for National Emancipation}

The defence industry is the alpha and omega of the project for the Turkification of the Turkish economy: the absence of an indigenous defence industry (more broadly of one employing advanced technology) is seen, first, as one of the main causes behind the Ottoman defeat against the Russian Empire in

1 Among the most fervent critics of the paradigm of development in Turkey are Fikret Baskaya (2005), Caglar Keyder (1993; 1987) and Ayşe Buğra (this volume). 
the XVIIIth century and, second, as one of the conditions necessary for 'national recovery' (Inalcik, 1992; Lafi, this volume). The multiple meanings of the Turkish term kalkınma - which conveys both 'development' and 'healing' (of an injured national psyche)—reflects this siege mentality of development in Turkey, by which the concept is seen not just as a way of improving conditions but in itself a condition of national survival. As a proof and a gauge of national emancipation and of an ambivalent relationship with Europe, linked to a traumatic past embodied in what is referred to as 'Sèvres syndrome'2 (Taner, 2005; Bayart, 2011; Schmidt, 2014) the project for the Turkification of the defence industry is both an affirmation and, simultaneously, a negation of imperial defeat. This ambivalence is characteristic of the Turkish collective melancholy vis-à-vis the Ottoman Empire (Celik, 2011). Development is therefore understood in terms of a double comparative process: a synchronic comparison with Turkey's Western partners and a diachronic comparison with its imperial past. The symbolic effectiveness of the idea of 'technological and civilising progress', ubiquitous in the major defence projects promoted by the AKP, is all the stronger in that it echoes national historiography (Copeaux, 1997) and the work of leading Turkish and foreign political scientists who present the Turkish army as a pioneering institution in the modernisation of the state and society, diametrically opposed to 'reactionary' Islamic forces (Ward and Rustow, 1965; Heper and Evin, 1988). This association between the army and modernisation was widespread both in the political thinking of the 1930s and among Third World thinkers from the 1950s through the 1970s. It is indicative of a 'desire for the state expressed through a generalised demand for modernity' (Hibou, 2011, 115). In an interpretation inspired by the 'educational protectionism' of Friedrich List, the formation of a national industry — especially the defence industry-is promoted as a condition of development and national security, deemed to safeguard the country from 'the fluctuations of war, foreign restrictions and commercial crises' (List, 1998, 275). Located halfway between 'high-tech Colbertism' (Cohen, 1992) and 'military Keynesianism' (Dunne, 2011; Krugman, 2011), this policy of promoting major industrial defence projects is seen as justified, on the economic level, by the promise of spillover effects in terms of jobs, improvements to the balance of trade, and technology transfer within both the defence sector and the civilian sector.

2 In Turkey, this expression is used to refer to the obsession with the idea of Turkey becoming encircled and the view that the state must survive: the reference is to the abortive 1920 treaty of the same name and to the draconian terms imposed on the Ottoman Empire by the victors of the First World War. 
Following the passing by Parliament of Law No. 3238 in 1985, which according to its first article aims to 'make progress in the defence industry and modernise the Turkish armed forces,', ${ }^{3}$ the projected Turkification of the defence industry benefited from completely new sources of funding. The law ensured the creation of an annual fund of USD one billion and a new Secretariat of State, both dedicated to the law's stated goal. This budgetary and administrative innovation was all the more paradoxical in that it contradicted the dominant security, political and economic paradigms of the day, at both the national and the international level. How indeed should we interpret the creation of this major and extremely expensive state project in the context of Atlanticist collective defence, of a return to civilian rule after three years of military rule, and of neo-liberal reforms advocating both the withdrawal of the state from economic activity and budgetary restrictions? While in 1980 the Turkish economy, at the behest of the military junta, moved from a closed model of industrialisation through import substitution to a model open to international competition, this plan to modernise the Turkish army and defence industry thus seems to be an exception to the neo-liberal rule, challenging both structural adjustments and a belief in the superiority of market rules promoted by international financial institutions. Therefore, this major project offers a particularly interesting way of gaining an understanding of the significance of the coexistence of dirigiste interventions and neo-liberal policies advocating the withdrawal of the state from the economy (Buğra, this volume).

\subsection{Defending Turkish Society from Its Allies? A Paradoxical Developmentalist Project}

Often reduced to a simple 'exit guarantee' (Cook, 2007) — that is to say, a negotiated condition of the political withdrawal of the military in 1983 in exchange for certain material gains - the aforementioned double innovation nonetheless also marked a certain 'civilianisation'. ${ }^{4}$ In the Turkish context, this term reflects the inclusion of the civilian Prime Minister (at that time Turgut Özal) in the decision-making processes surrounding arms purchases and the creation of a group of civilian experts within the new Secretariat of State dedicated to this major project. While reinforcing state intervention, this new law also contributed to the at least partial 'privatisation' of the related budget through the

3 Author's translation. In Turkish, the text reads, 'bu Kanunun amacı, modern savunma sanayiinin geliştirilmesi ve Türk Silahlı Kuvvetlerinin modernizasyonunun sağlanmasıdır'; Law no. 3238 , art. 1 (J.O. $7 / 11 / 85)$.

4 I use this term to describe the process of demilitarisation or at least the strengthening of civilian power vis-à-vis that of the army. 
use of dedicated extra-budgetary funds, ${ }^{5}$ to the benefit of the executive. These additional sources of finance ensure that parliamentary controls can be evaded de jure and contribute, in theory, to the development of a private defence sector in collaboration with, or complementary to, the public sector. Created in 1986, the private 'local' company FNSS (FMC-Nurol Savunma Sanayii A.Ş.), a major actor in this sector during the first decade of the new millennium, was thus the result of a partnership between the private Turkish holding company Nurol and the Us company FMC (later bought by the British company BAE Systems). The Foundation for Strengthening the Turkish Armed Forces (Türk Silahlı Kuvvetlerini Güçlendirme Vakfi, TSKGV), a private foundation that in 2013 owned many companies in the defence sector, also emerged as a major player during this period. ${ }^{6}$ In other words, in the 1980 s, this area was-at least in the national imaginary - a bridge between two seemingly contradictory visions of the role of the state, the Turkish army, and armaments in the national economy: the developmentalist vision and the neo-liberal one.

\subsubsection{A Traumatic Historical Trajectory}

In spite of all this, it is a difficult exercise to precisely date the beginning of the project for the Turkification of the defence industry (and more widely of the economy). It began well before the 1985 law since it even preceded the creation of the Turkish state in 1923 and has continued ever since-except during the Menderes years. The transition from Empire to nation state was echoed by an interpretation that stressed security issues in the country's external financial and technological dependence, resulting in a projected Turkification of the civil and military economy initiated in the era of the Young Turks. This was illustrated by genocide, forced evictions, expropriations and the violent eradication of a cosmopolitan bourgeoisie, mostly from the ethno-religious minorities of the Empire, in favour of a nascent bourgeoisie described by Baskin Oran as 'lahasümüt', an acronym in Turkish for 'secular, Hanafi, Sunni, Muslim and ethnically Turk': this bourgeoisie was considered more loyal to the Turkish state. This policy for the Turkification of the economy would be resumed in many different ways during the Republican period of the interwar years, particularly in the form of a wealth tax in 1942 (Bali, 2010; Buğra, 1994, 114-116), which allowed real property transfers at the expense of Turkish religious minorities,

5 Extra-budgetary resources designate state financial resources that are discretionary, flexible and partly private. They are neither included in the budget, nor subject to the normal budgetary procedures and controls.

6 The TSKGV came about due to the merger of three foundations dedicated, respectively, to each of the armed forces (land, sea, and air) and set up during the Cyprus crisis. 
particularly Jews, or even anti-Greek pogroms such as the one that took place in Istanbul in 1955 (Kuyucu, 2005; Bali, 2008). Turkey was co-opted by the Western bloc as part of its containment policy and its defence against the Soviet threat, illustrated by the country's accession to the North Atlantic Treaty Organization (NATO) in 1952: this ironically marked the suspension and subsequent re-legitimisation of this project of national emancipation vis-à-vis Turkey's Western allies. For while us military aid to Turkey—estimated to have been nearly USD 400 million between 1947 and 1951-played its part in enhancing the role of the Turkish army on the international and national stage, it also reduced the legitimacy and quality of the national arms industry (Truman, 1947; Orun, 1997; Kayaoglu, 2009; SSM, 2010). So much so that a great deal of the funding, equipping and training of the Turkish army under the Menderes Administration was 'outsourced': it was no longer a matter of national priority or even one of the prerogatives of the Turkish state, but fell under NATo's collective responsibility (Ahmad, 1993, 124). This co-optation also involved the formation of a 'deep state' (derin devlet), ${ }^{7}$ whose nerve centre was located in a special section of the Turkish army in direct contact with Western intelligence agencies, as part of Operation Gladio (Söyler, 2015, 101-102;Jenkins, 2009; Gingeras, 2015, 261-270). In other words, the extraversion policy of the Menderes Administration drastically reduced room for manoeuvre in the matter of armaments while contributing to the commodification of the Turkish army, to the extent that it even became one of the country's main 'export products' (ihraç), to cite one of the controversial expressions of George Soros (quoted in Evrensel, 2002). The military coup of 1960 and a return to protectionist practices inspired by Listian theory and Keynesian developmentalist policies did not change this situation. Only a shift in international opinion against Turkey in the 1960 s and the growing self-assertion of a national bourgeoisie attested

7 'The notion of the deep state may provide an appropriate starting point for investigations of how both foreign and domestic industrial magnates, bankers, intellectuals, and social activists engage and negotiate with bureaucratic and military agents seeking to overtly and covertly suppress dissent and promote the interests of governing regimes' (Gingeras, 2015, 267). According to Élise Massicard, in Turkey the phrase derin devlet refers to 'a vast web of corruption linking the crime industry, the highest levels of government, and death squads from the radical right' (Massicard, 2008, 63). This term is reminiscent of the concepts developed by Peter Dale Scott (1996), who uses the term 'deep politics' or even 'parapolitics' to refer to the illegal us activities conducted in collaboration with international organised crime. For if the term 'deep state' comes from Turkey, the collusive practices that result from the criminalisation, privatisation, and internationalisation of the state are found in many other countries. The concept was taken up and used during the Arab Spring to describe the way security apparatuses resisted change (Woertz, 2014; Momani, 2013). 
by the creation in 1971 of the first private employers' organisation, the Turkish Industry and Business Association (Türk Sanayicilerive Işadamları Derneği, TÜSIAD), once again made the necessity and legitimacy of the Turkification of the arms industry a priority (Buğra, 1994; Billion, 2000). The withdrawal of us missiles from Turkish territory in 1963 and the international embargoes on military sales imposed on Turkey during the Cyprus crisis revealed the adverse effects of excessive external dependence while renewing a national siege mentality vis-à-vis the country's Western partners (Billion, 2000; Şahin, 2002). This particular context contributed to the development of the private defence contractor Otokar, created in 1963 and owned by the Koç holding company, and the birth of several foundations that appealed for public donations to support national armament. These foundations made the creation of several companies possible, including Aselsan, currently the country's leading defence provider. ${ }^{8}$ However, it was not until the mid-1980s, once the emergency had passed and the economy had stabilised, that a significant public policy was implemented to carry out this major project of national development. So we are faced with a paradoxical situation: the 1960s and 1970s, usually interpreted as developmentalist, saw the privatisation of the defence industry in Turkey, while the period 1980-2010, usually seen as a neo-liberal period open to international trade and the rules of the market, was the scene of massive government intervention to foster the Turkification of this industry. This major project, the offshoot of the traumatic trajectory we have described, promoted the idea of national protection, an idea that was all the more desirable in that it coincided with a questioning of the social protection system that held sway under the yoke of the neo-liberal reforms adopted by the military junta.

\subsubsection{From Collective Defence to Turkish Self-defence: A Challenge to the Atlanticist and European Alliance?}

This major project, aimed at ensuring Turkey's strategic and industrial independence, also seems to reveal certain conflicts within the Western bloc, even putting certain historical caesura into perspective.

The desire to move from being a nation guaranteed by NATO (through the concept of 'collective defence' provided for in Article 5 of the North Atlantic Treaty) to being a nation also capable of self-defence recalls the prior experience of France. For this was how technological mastery of nuclear power was viewed in the 196os by the French government and a large part of the population: not as a defence against the Soviet threat, but as a tool to free themselves from American domination following the humiliation of Suez

8 The first two letters in the name Aselsan refer to the Turkish word asker, meaning soldier. 
(Vaïsse, 1992; Regnault, 2003). In Turkey as in France, the project of military self-empowerment - a technological, economic and industrial project-did not challenge the Atlanticist alliance. Instead, it allows the heterogeneous interests of the strategic partners to be fuelled. In the us, the Reagan Administration supported this Turkish project for commercial reasons: it would ensure the creation of a new market for us defence companies, as illustrated by two Turkish-American joint ventures-namely, FNSs (described above) and the Turkish Aerospace Industries (TAI), which is a partnership between Lockheed, General Electric and a Turkish company. TAI was created to ensure the assembly of F-16 American planes ordered by Turkey. The us government also had financial and strategic reasons for welcoming Turkey's endeavour to 'empower' itself. This was the time of the lavish Strategic Defense Initiative-nicknamed 'Star Wars' - that aimed to establish a missile defence system to protect the United States from attack by ballistic strategic nuclear weapons. The Turkish project and Turkish-American industrial alliances meant the financial burden on the us could be relieved while ensuring protection for America's Mediterranean flank. From the European standpoint, the goal of emancipating and modernising the Turkish defence industry was all the more readily accepted as European Member States had, with the exception of Germany, previously not been frequent partners in the Turkish arms market. Some member states also shared one of Turkey's aims: independence from us hegemony. Thus, French officials promoted, in the context of a 'variable geometry' European intergovernmental initiative known as 'Eureka', a 'Europe of technology' involving the development of a common European industrial research endeavour, both civilian and military, as an alternative to the 'Strategic Defence Initiative' established by the United States (Karsenty, 2006; L'Express, 1985).

The launch, in 1985, of this major project for the Turkification of the defence industry thus contributed to a rapprochement between Turkey and the European Economic Community (EEC). This rapprochement was ambiguous: it certainly allowed the proliferation of Turkish-European technological, industrial and military dependences in the form of various Turkish participations in European military-industrial projects (Airbus A40oM) and contracts for French, English and Italian firms; but at the same time this major Turkish industrial project contributed to a real arms race with Greece, beginning at the time of the Cyprus crisis. This was coupled with a diplomatic competition between Turkey and Greece for the EEC, of which the latter had become a member in 1981 (Sezgin, 2003; Andreous and Zombanakis, 2006). Alongside this equivocal integration of Turkey in European projects, the development of the Turkish national defence industry also aimed at opening Turkey up in economic and cultural terms to (Muslim) 'brother countries'. Supported by the 
United States as part of the 'green belt', ${ }^{9}$ this policy was intended, on the international level, to better address the Soviet threat and the threat of the Iranian Islamic revolution spreading across the region. Domestically, it resulted in the establishment of a 'Turkish-Islamic synthesis' (Eligür, 2010; Copeaux, 1997), promoted as a mechanism for the depoliticisation of Turkish society. This promotion, by the military junta, of Islam as an instrument of social pacification was all the more important as the sudden opening of the Turkish economy to global competition in the early 1980 s might well have led to a 'countermovement' (Polanyi, 1957), thus strengthening the Soviet Bloc. To a certain extent we find the same process at work in Egypt during the Sadat era (Vannetzel, this volume). In this regional context favourable to a cooptation of islam by military forces, the commercial diplomacy promoted by Prime Minister Özal and President Evren, himself a retired General, elected since 1984 Director of the Standing Committee for Economic and Commercial Cooperation of the Organization of the Islamic Cooperation, was meant to ensure the existence of a security rent for Turkey vis-à-vis the Gulf countries, so as to soften-in the short term - the budgetary impact of this project. In practice, however, despite numerous promises, only Libya imported arms from Turkey in the $1980{ }^{10}$

\subsection{From the End of the Cold War to the 'War on Terror': The Twofold Turkification of Both the Threat and the Defence Industry (1990-2001)}

Neither the disappearance of the Soviet threat nor the structural adjustments put in place to deal with major economic crises (1994 and 2001) brought the project to an end. Originally scheduled to run for a period of ten years, the Turkification of the defence industry was not only extended by parliament for a period of thirty years, the annual one billion dollar revenue was increased fivefold. This increase, in apparent discord with the international context of democratisation and the reduction of military spending (what is usually called the 'peace dividend'11), was the result of three main interrelated factors: the drying up of the international security rent, including us military aid; the increasing militarisation of the Turkish political and economic scene, which

9 This was the term used by Zbigniew Brzeziński, adviser to President Carter in the late 1970 .

10 See SIPRI (2014, annex) (Stockholm International Peace Research Institute), http://www .sipri.org/.

11 This expression is ascribed to George Bush and Margaret Thatcher, who used it in the early 1990s to refer to the advantages of lowering defence spending as a result of the disappearance of the Soviet threat. 
was accompanied by the development of the deep state; and the increasing number of criticisms and constraints to which Turkey was subjected by its European and American partners in matters of procurement and technology transfer - criticisms and constraints motivated by Turkey's multiple violations of human rights and its use of the armed forces against the Turkish civilian population of Kurdish origin.

\subsubsection{The Turkification of the Threat and of the Defence Industry: \\ The 'Low-Intensity' War on the PKK}

Despite their desire to achieve, by force of arms, the independence of those parts of Turkey where Kurds were in the majority, the guerrillas of the Kurdistan Workers' Party (Partiya Karkerên Kurdistan, PKK) were viewed throughout the 1980 s only as a minor threat by Turkish generals (Markus, 2007). ${ }^{12}$ However, they gradually became one of the main political, economic and symbolic resources of the Turkish military. Described as 'terrorists' and 'separatists', they were thus officially seen as replacing the Soviets as the main threat following the disintegration of the Soviet Union. The premature death of President Özal in 1993, himself of Kurdish origin and a supporter of a political solution to the Kurdish issue, unleashed an extreme militarisation of the political sphere that benefited the deep state: this was reflected particularly in an upsurge both in political killings and the disappearance of opponents of the government. In 1994 alone, the 'low-intensity war' on the PKK resulted in over 3,700 deaths and 1,400 villages being evacuated, not counting the numerous extrajudicial executions that took place (Yerasimos, 1994). This period, which followed the fall of the Berlin Wall, also helped to boost the black market trade in weapons in the region - a trade based on secret criminal agreements between complementary enemies (Massicard, 2008). Thus, in the middle of the Gulf War, 100,000 weapons manufactured by the Turkish public company Mechanical and Chemical Industry Corporation (Makina ve Kimya Endüstrisi Kurumu, M KEK) - weapons that had mysteriously vanished - reappeared in the hands of Kurdish fighters from Irak (Sabah, 2010a). The extreme violence and discrimination suffered by the Kurds at that time did not prevent certain forms of state co-optation. Indeed, such co-optation was rendered essential for the maintenance of Turkish military dominance in the region. This explains, in particular, the re-institution of village guards and the signing of important military contracts benefiting Aziz Yildirim. He was a Turkish businessman of Kurdish origin active in many fields, was head of the company Maktas, official suppliers to NATO since 1973

12 The РКк, a Marxist-Leninist party formed in 1978 to oppose the Turkish central government, officially launched its struggle in August 1984 with a simultaneous attack on several military facilities, and claimed it was acting in the name of Kurdish independence. 
and a partner of the company Siemens on several major projects for the Turkification of the defence industry (Radikal, 2011). ${ }^{13}$

This rise in violence in the east and the increasing number of obstacles placed in the way of arms imports from Europe ${ }^{14}$ explain the fivefold increase, in 1995, of subsidies to the programme for the Turkification of the defence industry, despite the lack of success enjoyed by what was then a ten-year project, and also despite the 1994 slump in the country and austerity measures demanded by the International Monetary Fund (IMF). In accordance with a circular logic, the very absence of a result can always be explained by the fact that it required more time and legitimises the endless renewal of a project (Rancière, 2004, 54-59). The urgency of the need for weapons to fight the PKK simultaneously fuelled a net increase in Turkey's external dependency, helping to keep the country-until early in the new millennium-among the top four importers of weapons in the world (Hen-Tov, 2004). Qualitatively, this period marked a diversification of Turkey's suppliers, with the establishment of a Turkish-Israeli agreement on military cooperation in 1996. At the time, this agreement entailed multiple benefits and synergies: respect for us alliances in the region, relative independence from European and American suppliers, common experience of armed struggle against an 'enemy within', the mutual strengthening of projects to ensure that each country ran its own arms industry, and finally the hope of slowing the rise of political Islam in Turkey (Nachmani, 2003).

2.2 .2

The 'Reactionary' Threat and the Postmodern Coup d'État in 1997:

The End of Military-Islamic Co-optation

In the 1995 parliamentary elections, the historic victory of the Welfare Party (Refah Partisi), an offshoot of the Islamic movement known as National Vision (Milli Görüş)—both led by Necmettin Erbakan, marked the end of

13 Aziz Yildirim has held a large number of positions. Since 1998, he has also been chairman of the famous football club Fenerbahçe, a club that is highly popular among Turkish military officers. In 2013, he also became the owner of Dearsan, an important shipbuilding company in the military sector that was in direct competition with Koç regarding the major military project of building MILGEM warship (from the Turkish Milli Gemi, National Ship).

14 The 1999 case of the German Leopard tanks is a good example of the political conditionalities imposed by European governments with regard to weapons supplied to the Turkish army. The German Red-Green coalition led by Chancellor Gerhard Schröder of the Social Democratic Party (SPD) and Vice Chancellor Joschka Fischer of the Greens agreed to the delivery of German tanks to Turkey on the sole condition that they were not used for domestic repression and that Turkey would improve its record on human rights (The Irish Times, 1999). 
the military-Islamic co-optation initiated in 1980 (Eligür, 2010; Sezgin, 2003). This reversal of alliances from Turkish-Islamic Synthesis was in some ways the paradoxical consequence of the success of the co-optation strategy and of the balance of power that favoured the Islamic party. A succession of corruption scandals (fostered by unbridled liberalisation in the absence of regulatory mechanisms), the negative social effects of the Customs Union with Europe and, finally, the 1996 Susurluk scandal — which revealed to the public, for the first time, the interdependence of elements of the security apparatus, the mafia and various co-opted Kurdish leaders-were all an implicit reinforcement of the legitimacy of Refah Partisi, which advocated the observance of Islamic morality (Massicard, 2008; Buğra and Savaşkan, 2014). The Welfare Party was a nationalist, positivist, Islamic, developmentalist and anti-capitalist project characterised in particular by a desire for reconciliation with the Kurdish population and hostility to the European project and to Turkey's membership of NATO (Yankaya, 2014). The party was hence likely to challenge the hegemony previously exercised by senior civil servants, including those in the military, a hegemony supported by part of the national bourgeoisie. This competition between hegemonic projects also had an entrepreneurial dimension: the rise of the Independent Industrialists and Businessmen Association (Müstakil Sanayici ve İşadamları Derneği, MÜSIAD), an employers' organisation very close to the Welfare Party, was starting to challenge TüsIAD's monopoly of access to state-owned tangible and intangible resources, bringing together a national bourgeoisie that was urban, secular, westernised and organically linked to the state (Buğra and Savaşkan, 2012; Yankaya, 2012). The Turkish defence sector was one of the main arenas of this political struggle: as a key element in the statist and developmentalist policy promoted by Erbakan (an engineer by training), it would in theory make an international, Islamic strategic alliance possible. Due to its specificity in terms of high level of opacity and large contracts, the defence sector in Turkey has always been a field of primitive accumulation. But being part of the defence sector is also an important source of prestige for both military and industrials as it is associated with advanced technology and nationalism. Those sectoral specificities explain the interest of the rising Islamic economic elite grouped within MÜSIAD to invest and compete in this new economic field (Çerçeve Dergisi, 1997). This is probably why, in September 1996, Deputy Prime Minister Tansu Çiller, the head of the True Path Party (Doğru Yol Partisi, DYP), a centre-right party that had tried to remove the Welfare Party from power, signed a defence contract worth nearly USD 5.5 billion in the absence of Prime Minister Erbakan (Hürriyet Daily News, 1996). The latter had embarked on a series of controversial visits to 'brother countries', including 
Iran and Libya, with the aim of setting up his own alternative project. Çiller's action meant that the redefinition of the project for the Turkification of the defence industry envisaged by the Prime Minister could be limited, as it was likely to endanger the material and strategic interests of the Turkish army, TÜSIAD and traditional Western partners. This competition between two competing hegemonic projects ultimately resulted in political Islam being re-evaluated as a security risk by the army. Despite the absence of direct violence, the 'reactionary' (irtica) threat, which echoed a traumatic historical memory, was now considered by the army to be a greater priority than the 'separatist' threat from the Kurds (Bozarslan, 2000). The memorandum of 28 February 1997, known as the 'postmodern coup', came to mark a further step in this indirect struggle with the Welfare Party and its supporters in civil society. It led, a few months later, to the resignation of the government led by Erbakan.

Many holding companies suspected of having financed the party and benefited from public contracts were later prosecuted for tax fraud and financial irregularities. Their managers were subsequently regularly ostracised at state visits and international fairs, including defence industry events in 1999 (Yankaya, 2012). The diversity of the roles played by the Turkish army on the national stage in the 1990s was nevertheless not just a matter of its own national historical trajectory; it reflected to some extent the reconfiguration of NATO's mission, as evidenced by the development in 1991 of a 'broader concept of security' including 'political, economic, social and environmental dimensions, in addition to the indispensable defence dimension' (NATO 1991, art. 25). The end of the co-optation of political Islam by the armed forces and the restoration of a pro-Western secular military hegemony at the expense of a democratically elected Islamic party could not fail to recall the cases of Algeria and Egypt in the 199os (Vannetzel, this volume). This attempt to restore military hegemony was, however, short-lived in Turkey. The arrest and extradition of PKK leader Öcalan, the historic slump in 2000-01, the opening of negotiations with the EU and the establishment of the AKP, an offshoot of pro-European and pro-capitalist political Islam, represented a challenge to military hegemony but did not end the major project for the Turkification of the defence industry (Tuğal, 2009). Rather, a merger occurred of competing Islamic and capitalist hegemonic projects and this changed the very terms of the Turkification of the industry (Tuğal, 2009; Haenni, 2005). While the 1990s were characterised by a dual Turkification process - the Turkification of the threat and the Turkification of the industry - the following decade saw the beginning of a new period of internationalisation of the Turkish security rent. Successive AKP governments have benefited politically, strategically and financially from the 'war on 
terror' (Islamic terror, that is) launched by President Bush following the attacks of 11 September 2001, while legitimising it only to a certain degree..$^{15}$

\section{A Project Central to AKP's 'Nationaliberal' Hegemony}

The establishment, early in the new millennium, of major structural and administrative reforms that followed the principles of 'new public management' promoted by the IMF, together with so-called democratisation reforms caught in the double stranglehold of European candidacy and the AKP, did not prevent the extension and intensification of the project for the Turkification of the defence industry. To some extent, the project weathered the historic financial crisis in Turkey in 2001 and even survived the significant budget restrictions and the widespread mistrust of the traditional economic and political elites brought about by that crisis. Similarly, the coming to power of the AKP in 2002, an event inseparable from the rise of a new Islamic bourgeoisie described by its opponents as 'green capital' (yesil sermaye), did not undermine the project, nor even the privileged position of the 'khaki capital' - secular bourgeoisie historically close to the military if not embedded.

\subsection{Reconfiguring Clientelist Practices}

With few exceptions, the 'green capital' so maligned by the secular elites seems to have remained secondary and marginal in the defence sector, reduced mainly to small and medium-sized enterprises (SMEs) and to subcontracting. ${ }^{16}$ It nevertheless benefited from positive discrimination under the new forms of assessment of the Turkification of arms projects that favour Turkish SME's involvement (Akça, 2010, 20; Jane's Defence Industry, 2011).

\subsubsection{Resistance of the Military-industrial Complex}

The Turkish army and the traditional, pro-Western, secular national bourgeoisie, grouped within TÜSIAD, remained the main beneficiaries of the project

\footnotetext{
15 In March 2003, the Turkish parliament rejected the Us military's request to use Turkish military installations as a base for its operations in Iraq.

16 Our hypothesis is based on SIPRI and Istanbul Chamber of Commerce and Industry reports. It remains, however, incomplete and disputable due to the suspension, since 2011, of the detailed annual activity reports published by the Turkısh Undersecretariat for Defense Industries (Savunma Sanayii Mustesarligi). The undersecretariat no longer provides regular and systematic information on defence contracts (size, beneficiaries ...) concluded under the auspices of the Turkification project.
} 
for the Turkification of the defence industry: in 2013, of the top seven defence companies in the country in terms of turnover, none were created after the electoral victory of the AKP, four were controlled by the Turkish army via the 'private' foundation TSKGV and only one, MKEK, was unrelated to TÜSIAD, due to its legal status as a public company (Table 12.1). TÜSIAD also operates a working group specifically dedicated to the defence sector.

Since the coming to power of the AKP, these companies have seen their sales increase tenfold (Table 12.2).

We see the same evolution with regard to the scientific and academic institutes absorbed by the military-industrial complex, as shown by the case of the Scientific and Technological Research Council of Turkey (Türkiye Bilimsel ve

TABLE 12.1 Main Turkish defence companies in 2013 (in terms of turnover)

\begin{tabular}{|c|c|c|c|c|c|}
\hline Rank & Name & $\begin{array}{l}\text { Date of } \\
\text { creation }\end{array}$ & Activities & Owners & $\begin{array}{l}\text { Employers' } \\
\text { affiliations }\end{array}$ \\
\hline 1 & Aselsan & 1976 & $\begin{array}{l}\text { Land forces } \\
\text { equipment and } \\
\text { electronics }\end{array}$ & $\begin{array}{l}\text { Army via TS KGV }(85 \% \\
\text { share). }\end{array}$ & Member of TÜSIAD. \\
\hline 2 & Otokar & 1963 & $\begin{array}{l}\text { Land forces } \\
\text { equipment: tanks, } \\
\text { armoured cars }\end{array}$ & Koç Holding. & $\begin{array}{l}\text { Koç is a founder } \\
\text { member of TÜSIAD. }\end{array}$ \\
\hline 3 & TAI-TUSAS & 1985 & Aeronautics & $\begin{array}{l}\text { Army via TS KGV and } \\
\text { Lockheed until } 2005 \text {. } \\
\text { Since then, } 55 \% \\
\text { TKGV/45\% SID. }\end{array}$ & Member of TÜSIAD. \\
\hline 4 & MKEK & 1930 & Artillery & Ministry of Defence & Public. \\
\hline 5 & Havelsan & 1989 & Electronics & Army via TS KGV & Member of TÜSIAD. \\
\hline 6 & Roketsan & 1989 & $\begin{array}{l}\text { Missiles and } \\
\text { rockets }\end{array}$ & $\begin{array}{l}\text { Army via TSKGV }(35 \%) \text {, } \\
\text { MKEK }(15 \%) \text {, Aselsan } \\
(15 \%) \text {, Kalekalip } \\
(10 \%) \text {, Others }(25 \%) \text {. }\end{array}$ & $\begin{array}{l}\text { Aselsan and } \\
\text { Kalekalip are } \\
\text { members of } \\
\text { TÜSIAD. }\end{array}$ \\
\hline 7 & FNSS & 1986 & $\begin{array}{l}\text { Land equipment: } \\
\text { tanks, armoured } \\
\text { cars }\end{array}$ & $\begin{array}{l}\text { Nurol Holding } \\
(59 \%) / \text { BAE Systems } \\
(41 \%)\end{array}$ & $\begin{array}{l}\text { Nurol is a member } \\
\text { of TÜSIAD. }\end{array}$ \\
\hline
\end{tabular}

SOURCES: AUTHOR'S COMPILATION OF DATA OBTAINED FROM THE RESPECTIVE WEBSITES OF THESE COMPANIES AND FROM THE 2013 RANKINGS OF THE TOP 500 INDUSTRIAL COMPANIES IN TURKEY DRAWN UP BY THE ISTANBUL CHAMBER OF COMMERCE AND INDUSTRY. 
TABLE 12.2 Exponential development of sales figures for the leading national companies in the defence industry between 2002 and 2014 (millions TRY)

\begin{tabular}{lccccccc}
\hline Name of company & $\mathbf{2 0 0 2}$ & $\mathbf{2 0 0 4}$ & $\mathbf{2 0 0 6}$ & $\mathbf{2 0 0 8}$ & $\mathbf{2 0 1 0}$ & $\mathbf{2 0 1 2}$ & $\mathbf{2 0 1 4}$ \\
& & & & & & & \\
\hline Aselsan & 318 & 358 & 489 & 695 & 982 & 1,369 & 2,141 \\
TAI-TUSAS & 104 & 106 & 272 & 304 & 418 & 404 & 1,726 \\
Otokar & 98 & 282 & 348 & 485 & 548 & 894 & 956 \\
MKEK & 44 & ND & ND & ND & ND & ND & 658 \\
Havelsan & 59 & ND & 183 & 208 & 186 & 372 & 406 \\
Roketsan & ND & ND & ND & 138 & 254 & 414 & 716 \\
FNSS & 321 & 181 & ND & ND & 171 & 287 & 330 \\
KaleKalip & ND & 90 & 149 & 188 & 254 & 290 & ND \\
& & & & & & & \\
\hline
\end{tabular}

Note: ND (not defined) means that the sales figures of the company are, for the year in question, lower than the sales figures recorded by any of the top 500 industrial companies in Turkey.

SOURCE: AUTHOR'S COMPILATION FROM THE ANNUAL RANKINGS OF THE TOP 500 COMPANIES IN TURKISH INDUSTRY CARRIED OUT SINCE 1997 BY THE ISTANBUL CHAMBER OF INDUSTRY.

Teknolojik Araştırma Kurumu, т ̈̈вІтак), the Turkish equivalent of the French Centre national de la recherche scientifique, and by prestigious universities such as the Technical University of the Middle East (Orta Doğu Teknik Üniversitesi), the Technical University of Istanbul (İstanbul Teknik Üniversitesi) and Boğazici University (Boğazici Üniversitesi). These institutions are the nurseries of the elite, comprising spaces for shared socialisation between members of the military, industrial, and scientific establishment, particularly in science parks; since 2006, these institutions have seen a tripling of the contracts related to the Turkification of military scientific knowledge. Created in 2010 through the merger of the Institute of Information Technologies (Bilişim Teknolojileri Enstitüsü, вTE) and the National Research Institute in Electronics and Cryptology (Ulusal Elektronikve Kriptoloji Araştırma Enstitüsü, UEKAE), the Informatics and Information Security Research Center (Bilişim ve Bilgi Güvenliği İleri Teknolojiler Araştırma Merkezi, BILGE M) —affiliated to т ÜвІтAК and specialising in information systems, cryptology and electronics—-has benefited greatly from this financial support. BILGEM was also one of the main sources of expertise when it came to discrediting several members of the military's leadership implicated in various major scandals, including Ergenekon and Balyoz (Sledgehammer). As a result, the increased dependence of тÜBITAK on contracts 
promoting the Turkification of the defence sector seems to reflect at once a militarisation, a commodification and an increased politicisation of scientific knowledge in Turkey under the AKP (Table 12.3).

The Turkish military, the government and the defence companies in TÜSIAD (and, to a much lesser extent, in MÜSIAD) thus form the 'triangle of power'17 (Wright Mills, 1956, 12), legitimised and strengthened by scientific expertise (Turse, 2009). It is still difficult to draw a distinction between these actors since the boundaries separating public from private, military from civilian, and foreign from national are porous. As the sector is characterised by many 'multipositionings' and widespread 'co-opetition'18 that calls into question 'the theoretical contradiction between competitive relations and collaborative relationships' (Bruno, 2008, 34), the major defence companies are successively or simultaneously customers, partners, competitors and, more rarely, 'suppliers' to other defence companies, both Turkish and foreign. Cross-participation between the main 'national' defence companies in Turkey, and the TurkishAmerican joint ventures (FNSS, TAI) described above illustrates these complex relationships, which also to be seen in major civil infrastructure projects (Table 12.1). Similarly, although six of the seven major companies in the sector

TABLE 12.3 The changing numbers of contracts allocated to TÜBITAK, the other great beneficiary of the Turkification of the defence industry, between 2006 and 2012 (millions TRY)

\begin{tabular}{lrrrrrrr}
\hline & 2006 & $\mathbf{2 0 0 7}$ & $\mathbf{2 0 0 8}$ & $\mathbf{2 0 0 9}$ & $\mathbf{2 0 1 0}$ & $\mathbf{2 0 1 1}$ & $\mathbf{2 0 1 2}$ \\
\hline TÜBITAK Sage & 24.1 & 31.1 & 58.9 & 91.1 & 70.1 & 56.3 & 83.9 \\
TÜBITAK Uzay & 12.5 & 16.7 & 21.6 & 22.2 & 27.8 & 30.8 & 36.2 \\
TÜBITAK UEKAE & 72.8 & 90.2 & 99.7 & 125.0 & & & \\
TÜBITAK BILGEM & & & & & 157.8 & 199.6 & 208.4 \\
Total & 109.4 & 138.1 & 180.2 & 238.3 & 255.6 & 286.7 & 328.5
\end{tabular}

SOURCE: YENTÜRK (2014).

17 A term used by C. Wright Mills, echoing in particular the speech given by President Eisenhower at the end of his second term of office in 1961. In it, the former general highlighted the risks posed by the impact that uncontrolled strengthening of the military-industrial complex might have on American democracy.

18 'Co-opetition' is the careful mix of cooperation and competition. The term was invented by Ray Noorda based on the nascent computer networking industry in the 8o's (Williamson, 2006). 
are legally private and civil, this by no means implies any simple privatisation or even 'civilianisation' of the sector. The TSKGV foundation, owner of twenty companies in the defence sector, is certainly a de jure private entity thanks to its status as vakif (mortmain), but it belongs de facto to the Turkish army. It is run by army officers and finances the military effort (Akça, 2010). Free competition and the distinction between political and economic spheres are all the more illusory in this sector in that the state remains a central and multipositional player. The state is the only customer of the national market; the only investor capable of funding such expensive, long, and uncertain projects. Whether obtaining national contracts, research grants, permits required for arms exports, offsets or state export guarantees, those working in the defence industry remain structurally dependent on the government. So 'the major vested interests [the military-industrial complex] often compete less with one another in their effort to promote their several interests than they coincide on many points of interest and, indeed, come together under the umbrella of government. The units of economic and political power not only become larger and more centralized; they come to coincide in interest and to make explicit as well as tacit alliances.' (Wright Mills, 1956, 266-267).

\subsubsection{Clientelist Practices and the 'Reciprocal Assimilation of Elites'}

This resistance on the part of traditional military-industrial players to the AKP government is not the result of the bar being placed too high for new entrants or even of the impotence of the government in the face of the aforementioned elites. It reflects instead a 'reciprocal assimilation of elites' (Bayart, 2006), and one might even say a reciprocal and asymmetric assimilation of the AKP and the traditional members of the military-industrial complex. The holding company Nurol is a particularly good example of this convergence of interests and this shared socialisation. This company owns Nurol Teknoloji, is a co-owner of the Turkish-British defence company FNSS, a member of TÜSIAD, a pioneer in the field of Turkish defence exports in 1997, and well established in the Asian markets (Malaysia and the Philippines) and the Middle East (Saudi Arabia). Like many other 'competitors' in the Turkish defence sector, such as SFTA and Profilo, the holding company Nurol is highly active in building and public works, and also receives public contracts for construction, reconstruction and weapons, not only in Turkey but also abroad-contracts that are characterised by discretionary government interventions (Buğra, this volume). These multiple interests and reciprocal yet asymmetric dependences have led to the formation of personal connections, as evidenced in 2012 by the presence of the then Minister of the Economy and the Mayor of Ankara at the wedding of the son of the Vice President of Nurol. Another such example is the 
shipbuilding company Yonca-Onuk, established in 1986. Its owner personally met Erdogan to promote its products abroad; this allowed him, for example, to access the Qatari and Egyptian markets (Özdemir, 2004; SIPRI ${ }^{19}$ ). The seizure by the state of the civilian and military vehicle producer BMC, the ownership of which was later transferred to the businessman and media tycoon Ethem Sancak - an active member of the Justice and Development Party (AKP) and MÜSIAD, a former member of TÜSIAD (2007-08) and very close to Erdoganonce again proved the centrality, in the defence industry, of personal connections with the government and the multipositional nature of this sector (Cumhuriyet, 2015; Buğra and Savaşkan, 2014; Yankaya, 2015).

Contrary to the neo-liberal fiction that sees the international attractiveness of Turkish armaments as residing in their competitiveness alone, it is the combination of political, financial and business support provided by the state to these defence companies that ensure their success. Co-optation by the government, essential if these companies are to sell arms, works not only at home but also abroad. According to Prime Minister Erdogan, 'While people can succeed in selling refrigerators and televisions by themselves, regarding the defence industry, a state guarantee is required; that is why we support this sector' (quoted in Özdemir, 2004).${ }^{20}$ Bound sales, known as offsets — that is to say, the military import contracts established by the Turkish state in return for the supplier country investing in or importing products or services from Turkey that are defence-related (direct offsets) or unconnected to the defence industry (indirect offsets), follow the same logic. According to some expert estimates, in 2013 offsets constituted nearly 70 per cent of Turkish exports in the field of defence and aviation, and almost all exports to so-called Western countries (Jane's Defence Industry, 2014c; Jane's Defence Industry, 2014b). Officially set up in order to limit the negative effects of imports on the balance of payments, such practices-widespread in the international defence sector-run against the idea of free competition. Protected by a double seal of privacy (they are treated as top secret and are at the same time trade secrets), they encourage and to some extent legitimise the formation of rents for co-opted national businesses. They thus contribute to the development of clientelist practices, understood not only as 'the existence of a pragmatic exchange of goods and services in return for support and votes' but also as 'the fact that the reciprocity thus established can turn into a bond of political allegiance and the dependence thus

\footnotetext{
19 SIPRI, http://www.sipri.org/.

20 Author's translation. In the original Turkish: 'biz bu Türk savunma ürünlerini destekliyoruz, insanlar buzdolabını telvizyonu kendi başlarına satabilirler ama savunma ürünleri için devletlerin referansı gerekir o nedenle destekliyoruz'.
} 
created can be recognised as legitimate' (Briquet 1995, 77). While it is undeniable that this policy is explained by the desire to strengthen the prestige of the state, both internationally and nationally, particularly through the increasing number of its extensions into so-called civil society, it seems legitimate to wonder about the existence of the AKP's direct financial interests in the development of this particular industry. Though they do not prove this hypothesis, the corruption cases related to the sales of Turkish arms by the company Havelsan to South Korea or the sale of German Thyssen Krupp submarines to the Turkish army, the huge amounts involved, their growing opacity, the practice of retrocession-quite common in this sector-and the recent accusations of corruption that have tainted the reputation of the AKP government appear at least to provide evidence in support of it (Bekdil, 2015, The Korea Times, 2015; Cumhuriyet, 2016). ${ }^{21}$ The project for the Turkification of the defence industry thus involves the proliferation of asymmetrical interdependences between military, industrial, scientific and political elites underpinning the formation of a shared interest in this major project. As I was told by one of the experts in the field, 'none of the defence officials will refuse a major Turkification project. Even if they fail, or if the major project turns out to be impossible, the government will have no interest in making their failure public knowledge. ${ }^{22}$

\subsection{The Major Project of Turkification: A Hegemonic Instrument of Extraversion}

This major project of Turkification and the practices of co-optation or even clientelism that underlie it have not, in the least, led to the suspension of external links. They are, rather, an expression of a strategy of extraversion based on increasing external dependences. And these dependences are the vectors of a circulation of economic, political, technological and symbolic resources, which - taken as a whole-contribute to a quest for hegemony both nationally and on the regional and international levels.

3.2 .1

An Instrument of National Affirmation and International

Negotiations

As an instrument for equalising power relations with its Atlanticist partners, the project enables Turkey to play with and play on diplomatic and technological dependences with Western suppliers so as to assert itself more strongly on the national level. Thus, for example, partner countries that affront Turkish national 'feelings' and official historiography have been punished

21 Concerning thıs growing capacity of public defence expenditure, see Footnote 15.

22 Interview with a journalist and expert on defence industry, Ankara, April 2015. 
and allied countries deemed more respectful and loyal have been rewarded. French defence companies were subjected to this carrot-and-stick policy in 2001 when, following the passing of a law recognising the Armenian genocide, they experienced a freezing of military contracts with Turkey even though the Turkish army had hitherto been one of the main foreign customers of the French defence industry. This ostracism was renewed in 2006 when a bill was proposed criminalising the denial of the Armenian genocide (Jane's Defence Industry, 2012). The same applied to contracts won by Israel, which were suspended for 'technical reasons' following the resumption of the conflict in Gaza and the affair of the Mavi Marmara flotilla in 2010, which claimed the lives of nine Turkish civilians. South Korea and China have since taken over from the main 'Western' suppliers, while allowing Turkey to obtain significant concessions in terms of technology transfer. Thus, the recent success of a Chinese company (China Precision Machinery Import-export Corporation, CPMIEC) in the context of the Turkish call to tender for the establishment of a national air missile system to complement the protection afforded by NATO-a call estimated to be worth several billion USD-attracted significant criticism and pressure from NATO members, notably expressed through the withdrawal of Patriot missiles protecting Turkish territory (Jane's Defence Industry, 2013; Marcou, 2015). Accused of jeopardising the security and solidarity of the Atlanticist alliance through this agreement with a Chinese company subjected to sanctions by the Us for its contribution to nuclear proliferation in Iran and North Korea, Turkey was strongly 'invited' to review its choice in favour of one of its Atlanticist allies Lockheed or Eurosam-American and Franco-Italian companies, respectively (Jane's Defence Industry, 2014a; Kemal, 2014). While the contract has not been finalised, Western competitors have, in the meantime, offered better conditions. The French government, indirectly competing for this contract, notably maintained a low profile during the centennial of the Armenian genocide commemorated on 24 April 2015, and thus minimised friction in Franco-Turkish trade relations (Jane's Defence Industry, 2012). ${ }^{23}$

In other words, this Turkification project is not only a guarantor of national honour on the international stage; it also helps to strengthen the country's ability to negotiate with the largest variety of foreign suppliers and to force them

23 The importance that the French government ascribes to its military and strategic relationship with Turkey is also reflected in the profile of the French ambassador to Ankara, in place from 2011 to 2015: a former chair of the military and civilian cabinet of the French Ministry of Defence. The same is true of the Consul General of France to Turkey, in place since 2013: she was previously the Deputy Director of French Strategic Affairs, Security and Disarmament. 
to compete for contracts on the best terms. The project still does not, however, allow Turkey to emancipate itself from its Atlanticist allies: the us still largely dominates the market as the source of nearly 70 per cent of Turkish armament imports in 2014. ${ }^{24}$ Even those weapons presented as 'one hundred per cent Turkish' by the Turkish authorities, including the Atak helicopter or the Anka drone-symbols of technological and political national independence-still rely on many different foreign licences, including American licences, which prevent their use and export without the consent of Western partners (Sözcü, 2015; Timetürk, 2012).

3.2 .2

A Muslim Civilizational Development Project: High-Tech

Port by MÜSIAD

The strong internationalisation of the Turkish defence industry under the AKP, evidenced by its export performance and by the creation in 2011 of the Union of Exporters of the Defence Industry and Aeronautics (Savunma ve Havacilik Sanayi İhracatçilari Birliği, ssi), reflects the transition from a logic of means to a logic of results, characteristic of the neo-liberal period. Since 2011, when the Turkish arms industry officially achieved $5^{0}$ per cent autonomy, the issue of the origin of production and its components is no longer central in gauging the success of local development. It has been replaced by two goals: the tripling of the turnover of Turkish defence companies and the doubling of Turkish arms exports. The aim is to grow these exports from USD 1-2 billion for the period 2012-16 to USD 20 billion in 2023-the centenary of the Turkish Republic (Jane's Defence Industry, 2012). İ order to achieve this objective, the AKP government has relied on economic and cultural extraversion with regard to friendly 'brother' countries, particularly including those in the Gulf and countries that have experienced the Arab Spring (Tunisia and Egypt). It is reminiscent of the aforementioned earlier attempts to develop economic, political and strategic ties with Muslim countries conducted by premiers Turgut Özal in the early 1980s and Necmettin Erbakan in the mid-199os, respectively.

The project 'High-Tech Port by MÜSIAD' is an example of a reciprocal assimilation of elites on the international scale, promoted by the AKP government: the main Turkish defence companies, members of TÜSIAD, have thus found themselves being co-opted by MÜSIAD, which itself promotes a transnational 'market Islam' (Haenni, 2005; Yankaya, 2015). This alliance combines the technological know-how-accumulated over several decades-of various members of TÜSIAD and market access to so-called Muslim countries thanks to MÜSIAD's international networks. All of this contributes to the influence and 
prestige of the AKP nationally and internationally (Yankaya, 2015). Presented at the end of 2014 under the auspices of President Erdogan and several Turkish ministers at the 15th International Fair of MÜSIAD, High-Tech Port officially aims to place Turkish know-how at the service of 'brother countries' to ensure no 'clash of civilisations' but a Muslim 'civilisational competitiveness' vis-à-vis Western countries (Dünya, 2015a). This project, presented as a 'showcase' for Turkish technological excellence, was again at the heart of the meeting held in October 2015 in Qatar, in tandem with the International Business Forum, which was then devoted to 'partnerships in industry and defence between Islamic countries' (Yankaya, 2014 and 2015). A binational fair exclusively dedicated to the fostering of Qatari and Turkish companies was organised under the auspices of the Turkish President, Prime Minister and Minister of Defence and the Qatari Sheikh Bin Hamad bin Halifa es-Sani. The family links and Ottoman origins of this Qatari have also been highlighted by MÜSIAD so as to better legitimise this example of Turkish-Qatari co-optation and naturalise the military agreement established the same year (Dünya, 2015b). This provides for a mutual defence clause in the case of attack, which de facto means that the Turks will provide Qatar with military protection should aggression occur (Toyay, 2015; Gurcan, 2015). The political entrepreneur Ethem Sancak, who had shortly before given up a portion of his shares in the company в MC to the Industrial Committee of the Qatari Armed Forces, acted as a bridgehead for Turkish-Qatari relations, playing a significant role as an intermediary (Star, 2015).

However, far from signifying equality between 'brother' countries, the fact that Turkey has resorted to the argument for Muslim transnational solidarity in the defence market contributes rather to a commodification of Islam and to a 'euphemisation' or legitimisation of the inequality, conflict and competition between the countries that make up this imaginary umma. The 'civilisational competition' with Western forces is indicative of a quest for complementary status with brotherly countries. The brotherhood discourse promoted by this project is a purely superficial horizontality, and reveals an attempt to justify the international division of labour within the so-called Muslim world in favour of Turkey, involving the exclusion of Iran and its allies. High-Tech Port promotes the idea of the civilising and cultural superiority of Turkey over Arab countries; the 'big brother' among its 'brother countries' (Yankaya, 2015). This erasure of the logic of social justice and equalisation of the relationship between 'brother countries' to some extent echoes the theology of American neo-Protestant prosperity by activating an 'imaginary of social success where money becomes both the site of the great revenge and the sign of a divine election' (Haenni, 2005, 65, our transl.). Far from the heroic spirit of the 'great 
civilisational development' promoted by Nail Olpak, president of MÜSIAD, the policy of exporting Turkish arms to 'brother countries' reflects a certain pragmatism on the part of the government in the face of the low competitiveness of the Turkish defence industry in comparison with Western technology. It also results from a multitude of logics to be found in importing countries, inherited in part from their own historical trajectories: the shared experience of facing an embargo on their arms markets (Pakistan and Indonesia), the parallel policy of importing countries that aims to make their defence industries independent (Pakistan, Qatar and Malaysia) and the comparative historicity of bilateral ties between individual importing countries and Turkey or Iran, respectively. Finally, the attractiveness of Turkish arms for Muslim-majority countries is inseparable from the ambiguous nature of Turkey's membership of NATO, sometimes 'euphemised' and sometimes highlighted by the Turkish government in its search for international hegemony.

Thus, this project of Turkification reveals complex and organic relations with Western partners and 'brother countries'. Located at the intersection of the strategy of extraversion and that of redistribution of public resources to Turkish and foreign political entrepreneurs, the project is part of a national and international quest for hegemony. It illustrates a 'combination of globalisation and the universalisation of the nation-state' typical of the concept of 'national liberalism' (Bayart, 2012, 5).

4

2013: Year of Reaffirmation or Challenge to the Cause of Hegemony?

Internationally, the violent evolution of the Arab Spring, which turned against the new leaders who had emerged from political Islam and been co-opted by the AKP, strengthened the ties between Turkey and Qatar; witnessing in particular an exponential increase in Turkish exports to Qatar since 2012. ${ }^{25} \mathrm{Na}$ tionally, the Gezi Park protests against the Turkish government in 2013 and the disastrous effects of the latter's neo-liberal politics in environmental, urban and social terms have considerably undermined the process of mutual assimilation of certain elites. This is the case of the most powerful holding company in the country, $\operatorname{Koc}(\mathrm{Cemal}, 2013)$. As one of the main beneficiaries of the Turkification of the defence industry hitherto pursued by the AKP through its subsidiaries RMK and Otokar, the Koç family was accused of supporting the Gezi protesters. The eponymous holding company has since seen its USD 2 billion

25 SIPRI, http://www.sipri.org/. 
military contract for building the 'hundred per cent Turkish' MILGEM warship ${ }^{26}$ cancelled on a mere technicality while its principal operating subsidiaries in the energy sector-Tüpras, Opet and Aygaz-were subjected to a tax audit (Gursel, 2013). Similarly, тÜ BITAK, a key player in this major project, suffered a veritable witch-hunt following the deterioration of relations between the Gülen community and President Erdogan, worsened by the Gezi Park movement and the revelation, on 17 December 2013, of the existence of a vast network of corruption involving key members of the government and their respective families, attributed to Gülen's followers. Formerly a key AKP ally, closely integrated into state bodies, the community is now ostracised, being considered by the government to be a terrorist 'parallel structure'. This change in alliances has resulted in the abrupt and massive dismissal of hundreds of employees of тÜвIтAK suspected of sympathising with Hizmet. ${ }^{27}$ It has simultaneously made possible a reversal of power relations through a rapprochement attempt by the AKP with some militaristic and nationalist elites who were 'victims' of the scientific expertise contributed by тёвІтак in the Ergenekon and Balyoz (Sledgehammer) trials, formerly backed by AKP government. The vice president and director of the BILGEM laboratory, the main source of judicial expertise in both the aforementioned cases and the main beneficiary of research funds for the Turkification of the defence industry since 2010 (Table 12.3), were not only dismissed but also prosecuted for illegally bugging Erdogan's offices in 2011 (Saymaz and Çelikkan, 2015).

This breakdown of the alliance by economic means, against the new enemies within, is a counterpart to the postmodern coup of 1997 (Cemal, 2013). Gezi Park and the Arab Spring have thus, among AKP leaders, recalled traumatic memories of a military coup past and triggered fears of a new reversal, while contributing paradoxically to bolstering military legitimacy through the aforementioned changes in alliances at the expense of the Gülen movement and the halting of the embryonic peace process with the PKK. Thus, the mutual dependences, both material and immaterial, promoted by the major project of Turkification, in no way reflect the existence of harmonious relations or even any stability of interest between government, industry and the military (Wright Mills, 1969, 31). As they depend on the power relations of the moment, the conflicts that constitute this highly publicised and marketed development project may lead to reversible co-optations.

\footnotetext{
26 MILGEM comes from Milli Gemi, meaning 'National Ship'.

27 The word Hizmet means 'the service' in Turkish and is used to refer to the Gülen movement in Turkey.
} 
The major project for the Turkification of the defence industry, promoted simultaneously as an example, a condition and evidence of national development, is thus based on a 'constitutive imagination' (Veyne, 2014); a siege mentality following a historic path structured by the trauma of the turn of the century. The multiple meanings of kalkinma, the Turkish term for development, reveals this very clearly. However, this project 'makes do with' dependences and external resources, be they economic, technological, political or military, and expresses a quest for a 'nationaliberal' hegemony that is unstable and reversible. Playing with and playing on relations of inequality at the international level, it helps to alter, if only in the imaginary, the ways in which Turkey is integrated into the international system, ensuring a fictitious commodification of the umma and the Turkish army in the name of the defence of Turkish society. This project thus represents an imaginary bridge not only between the logic of the market and the logic of national affirmation, but also between political Islam and the secular elite. Neither true nor false (because it is not externally verifiable), this great development project at the heart of the government's legitimacy is a real fiction with multiple domination effects, acting as a matrix for the accumulation, conversion and circulation of economic, symbolic, political and religious capital. Beyond the circle of elites belonging to the military-industrial complex, the lack of public criticism vis-à-vis this major yet extremely expensive militarist project, both uncertain and synonymous with lethal consequences for much of the Kurdish civilian population, also expresses a form of consensus, whether mandatory or not. ${ }^{28}$ As the product of a true 'normative grammar' (Gramsci, 1977), this major project offers Turkish citizens an imaginary national protection, replacing to some extent the state-provided social protections that have been undermined by neo-liberal reforms. The project thereby contributes to a certain endorsement of state power and to the emasculation of a nascent potential 'countermovement' (Polanyi, 1957) by answering the 'citizens' desire for the state' (Hibou, 2011, 82), understood in terms of modernity, unity, prestige, sublimity and equality. For the civilian populations potentially affected by this major project, a public challenge to the last of these would constitute evidence of their betrayal of the Turkish state, as this project remains

28 'By mandatory consensus, I mean a set of opinions, judgments, and public behaviours required of citizens in connection with certain values (Kemalism and its principles), certain facts or events of the present (the war in Kurdistan, the presence of the Turkish army in Cyprus) or the past (the Armenian genocide), and certain institutions (the army, the army's control of the government)' (Copeaux, 2000). 
so closely associated with the survival of the state and the nation. Thus, unlike large civil infrastructure projects, this major project is relatively free of critics because of the many forms of legitimacy it bears and the impossibility of casting doubt on the achievements claimed for it because of the double secrecy that it enjoys (it is both a trade secret and top secret). As a result, the project contributes to an unfinished depoliticisation of social inequality (Ferguson, 1994) in Turkey. Similarly, the commodification of Muslim solidarity, and the 'civilisational competition' it promotes, depoliticises inequality between socalled Muslim countries. This 'nationaliberal' consensus, located at the heart of the quest for AKP hegemony both nationally and internationally, appears nevertheless to be questioned today by the normalisation of diplomatic relations with Iran and the recent disclosure of secret Turkish arms shipments to Syria (The Guardian, 2016).

\section{References}

Ahmad, F. (1993) The Making of Modern Turkey (London; New York: Routledge).

Akça, I. (2010) 'Military Economic Structure in Turkey: Present Situation, Problems and Solutions', TESEV Democratization Programme. Policy Report Series (Istanbul: TESEV), http://tesev.org.tr/wp-content/uploads/2015/11/Security_Sector_Policy_Re port_2_Military_Economic_Structure_In_Turkey.pdf (accessed on 23 May 2016).

AKP (Adalet Kalkima Partisi) (2012) AKP Parti 2023 Siyasi Vvizyonu: Siyaset, Toplum,

Dünya, 30 September, https://www.akparti.org.tr/site/akparti/2023-siyasi-vizyon (accessed on 21 December 2015).

Andreous, A. and G. Zombanakis (2006) 'The Arms Race Between Greece and Turkey: commenting on a major unresolved issue', Peace Economics Peace Science and Public Policy, 12(1), DOI: 10.2202/1554-8597.1092.

Bali, R. (2010) L'affaire impôt sur la fortune (Istanbul: Libra Yayınevi).

Bali, R. (2008) 'The 1934 Thrace Events: Continuity and Change within Turkish State Policies Regarding non-Muslim Minorities. An Interview with Rifat Bali', European Journal of Turkish Studies, No. 7, http://ejts.revues.org/2903 (accessed on 23 May 2016).

Baskaya, F. (2005) Kalkinma iktisadinin yükselisi ve dususu (Ankara: Türkiye ve Ortadogu Forumu Vakfi).

Bayart, J.-F. (2012) Sortir du national-libéralisme (Paris: Karthala).

Bayart, J.-F. (2011) 'La nouvelle confiance en soi de la Turquie', Dossiers du CERI, pp. 1-4, https://hal-sciencespo.archives-ouvertes.fr/hal-01024169 (accessed on 23 May 2016).

Bayart, J-F. (2006), L'Etat en Afrique. La politique du ventre (Paris: Fayard). 
Billion, D. (2000) La politique extérieure de la Turquie: Une longue quête d'identité (Paris: L'Harmattan).

Bekdil, B. (2015) 'Bribes paid but not taken', Hürriyet Daily News, 18 March, http://www .hurriyetdailynews.com/bribes-paid-but-not-taken.aspx?pageID $=449 \& n I D=79815$ \&NewsCatID $=398$ (accessed on 2 June 2016).

Bozarslan, H. (2000) 'Le madhisme en Turquie: “Lincident de Menemen” en 1930', Revue des mondes musulmans et de la Méditerranée, 91-94, http://remmm.revues .org/261 (accessed on 23 May 2016).

Briquet, J.-L. (1995) 'Les pratiques politiques “officieuses": clientélisme et dualisme en Corse et en Italie du Sud', Genèses, 20, http://www.persee.fr/doc/genes_1155-3219 _1995_num_20_1_1308 (accessed on 24 May 2016).

Bruno, I. (2008) 'La recherche scientifique au crible du benchmarking. Petite histoire d'une technologie de gouvernement', Revue d'Histoire Moderne et Contemporaine, 5(55-4bis), pp. 28-45, http://www.cairn.info/revue-d-histoire-moderne-et-contem poraine-2008-5-page-28.htm (accessed on 24 May 2016).

Buğra, A. (1994) State and Business in Modern Turkey: A Comparative study (New York: Suny Press).

Buğra, A. and O. Savaşkan (2014) New Capitalism in Turkey: The Relationship Between Politics, Religion and Business (Northampton: Edward Elgar).

Buğra, A. and O. Savaşkan (2012) 'Politics and Class: Turkish Business Environment in the Neoliberal Age', New Perspectives on Turkey, 46, DOI: 10.1017/So896634600001503.

Celik, B. (2011) Technology and National Identity in Turkey, Mobile Communications and the Evolution of Post-Ottoman Nation (London: I.B. Tauris), pp. 17-49.

Cemal, H. (2013) 'TÜPRAŞ örneği: 28 Şubat'ın ayıplan niye tekrarlanıyor', T24, 31 July. http://t24.com.tr/yazarlar/hasan-cemal/tupras-ornegi-28-subatin-ayiplari-niye-tek rarlaniyor,7142 (accessed on 27 April 2016).

Çerçeve Dergisi (1997) 'Türk Savunma Sanayii Türkiye'nin Stratejik Konumu’, Müsiad, 19. Certeau, M. (1990) L'invention du quotidien, 1. Arts de faire (Paris: folio essais).

Cohen, E. (1992) Le Colbertisme high-tech: Economie des Telecom et du Grand Projet (Paris: Hachette).

Cook, S. (2007) Ruling but not Governing: the Military and Political Development in Egypt, Algeria and Turkey (Baltimore: John Hopkins University Press).

Copeaux, E. (2000) 'Le consensus obligatoire', in I. Rigoni (ed.), Turquie: Les mille visages. Politique, religion, femmes, immigration (Paris, Syllepse).

Copeaux, E. (1997) Espaces et Temps de la nation turque: analyse d'une historiographie nationaliste (1931-1993) (Paris: CNRS Editions).

Cumhuriyet (2016) 'Denizalti ihalesinde Almalardan rusvet', 16 February, http://www .cumhuriyet.com.tr/haber/diger/482393/Denizalti_ihalesinde_Almanlardan_rus vet.html (accessed on 27 April 2016).

Cumhuriyet (2015) 'Askin meyvesi', 20 May, http://www.cumhuriyet.com.tr/koseyazi si/280237/Askin_meyvesi.html (accessed on 26 April 2016). 
Dale Scott, P. (1996) Deep Politics and the Death of JFK (Berkeley: California University Press).

Dunne, J.P. (2011) Military Keynesianism: An Assessment, Paper presented at the Second International Conference on Conflict Management, Peace Economics and Peace Science, November 2010, Central University of Finance and Economics, Beijing, http://carecon.org.uk/DPs/1106.pdf (accessed on 24 May 2016).

Dünya (2015a) 'Türk Savunma Sanayii Katar'dan Yogun rekabeti hazir', 2 October.

Dünya (2015b) 'Kalkinma medeniyeti projesi High Tech Port by Müsiad Qatar', 2 October.

Eligür, B. (2010) The mobilization of Political Islam In Turkey, (Cambridge: Cambridge University Press).

Evrensel (2002) 'Ihraç malimiz asker mi?', 20 May. http://www.evrensel.net/haber/ 130956/ihrac-malimiz-asker-mi (accessed on 25 April 2016).

Ferguson, J. (1994) Anti-Political Machine: Development, Depoliticization and Bureaucratic Power in Lesotho (Minnesota: University of Minnesota Press).

Gingeras, R. (2015) Heroin, organized crime and the making of modern Turkey (Oxford: Oxford University Press).

Gramsci, A. (1977) Gramsci dans les textes. Recueil de textes réalisé sous la direction de François Ricci en collaboration avec Jean Bramant (Paris: Editions sociales).

Gurcan, M. (2015) 'Turkey-Qatar, what are Turkish troops going to do in Qatar?', Al Monitor, 3 June, http://www.al-monitor.com/pulse/originals/2015/o6/turkey-qatar -what-are-turkish-troops-going-to-do.html (accessed on 25 April 2016).

Gursel, K. (2013) 'Is Audit of Koç Group Erdogan's Revenge for Gezi Park?' Al Monitor, 29 July, http://www.al-monitor.com/pulse/originals/2013/o7/koc-audit-raid-turkey -interest-rate-lobby-gezi.html (accessed on 27 April 2016).

Haenni, P. (2005) L'islam de marché: l'autre révolution conservatrice (Paris: Seuil).

Hen-Tov, E. (2004) 'The political economy of Turkish military modernization', Middle East review of International Affairs, 8(4).

Heper, M. and A. Evin (1988) State, Democracy and the Military: Turkey in the 8o's (New York: de Gruyter).

Hibou, B. (2011) Anatomie politique de la domination (Paris: La Découverte).

Hürriyet Daily News (1996) 'Erbakan bypassed in Key Defense Projects Plans Revenge on Ciller', 21 October, http://www.hurriyetdailynews.com/erbakan-bypassed-in-key -defense-projects-plans-revenge-on-ciller.aspx?pageID=438\&n=erbakan-bypassed -in-key-defense-projects-plans-revenge-on-ciller-1996-10-21 (accessed on 26 April 2016).

Inalcik, H. (1992) 'Some Remarks on the Ottoman Turkey's Modernization Process', in Ihnsanoglu, E. (ed.) Transfer of Modern Science and Technology to the Muslim World (Istanbul: Research Center for Islamic History, Art and Culture), pp. 49-59.

Jane's Defence Industry (2014a) 'Turkey Begins T-Loramids talks with Eurosam', 10 September, (London: Jane's Defence Weekly). 
Jane's Defence Industry (2014b) 'Offset obligations in Turkey exceeded USD 18 billion in 2013, SSM says', 1 June, (London: Jane's Defence Weekly).

Jane's Defence Industry (2014c) 'Turkish industry announces 2013 export figures', 1 February (London: Jane's Defence Weekly).

Jane's Defence Industry (2013) 'Turkey selects Chinese HQ-9 SAM for T-Loramids', 1 October (London: Jane's Defence Weekly).

Jane’s Defence Industry (2012) ‘Genocide law jeopardises France’s bid to supply missiles to Turkey', 1 February (London: Jane's Defence Weekly).

Jane's Defence Industry (2011) 'Turkish defence firms obliged to outsource and export under reforms', 1 September (London: Jane's Defence Weekly).

Jenkins, G.H. (2009) Between facts and fantasy: Turkey's Ergenekon investigation, Silk Road Paper, (Washington, D.C. and Stockholm: Central Asia Caucasus Institute Silk Road Studies program), http://www.silkroadstudies.org/publications/silkroad -papers-and-monographs/item/13091-between-fact-and-fantasy-turkeys-ergenekon -investigation.html (accessed on 24 May 2016).

Karsenty,J.-P. (2006) Du Cesta à la création d'Eureka:Réflexions de la politique scientifique et technologique du gouvernement socialiste (Paris: Institut François Mitterrand), 17 December, http://www.mitterrand.org/Du-CESTA-a-la-creation-d-EUREKA.html (accessed on 21 December 2015).

Kayaoglu, B. (2009) 'Strategic Imperatives, Democratic Rhetoric: The United States and Turkey, 1945-52', Cold War History, 9(3), DOI: 10.1080/14682740902981403.

Keyder, C. (1993) Ulusal Kalkinmaciligin Iflasi (Istanbul: Metis).

Keyder, C. (1987) State and Class in Turkey: A Study in Capitalist Development (London: Verso).

Kemal, L. (2014), 'Turkey missile maneouver', Today's Zaman, 3 November.

Krugman, P. (2011), 'Coalmines and Military Keynesians', New York Times, 28 octobre, http://krugman.blogs.nytimes.com/2011/10/28/coalmines-and-military-keynesi ans/?_r=o (accessed on 23 May 2016).

Kuyucu, A.T. (2005) 'Ethno-religious "unmixing" of Turkey: 6-7 September riots as a case in Turkish nationalism', Nations and Nationalism, 11(3), pp. 361-38o, DOI: 10.1111/j.1354-5078.2005.00209.x.

L'Express (1985) 'Les lumières d'Eurêka', 26 April, http://www.cvce.eu/obj/les_lumieres _d_eureka_dans_l_express_26_April_1985-fr-3ad525b8-57b1-4a82-bfic-7127709ef24a .html (accessed on 26 April 2016).

List, F. (1998) Système national d'économie politique (Paris: Gallimard).

Marcou, J. (2015) 'L'affaire des missiles chinois', Ovipot, 20 February, http://ovipot.hy potheses.org/10930 (accessed on 16 April 2016).

Marcus A. (2007) Blood and Belief: The PKK and the Kurdish Fight for Independence (New York: New York University).

Massicard, E. (2008) 'Le politique à l'articulation entre institution de sécurité et univers criminel: les bandes en uniforme en Turquie', in Briquet, J.-L. and G. Favarel 
Guarrigues (eds.) Milieux criminels et pouvoir politique: les ressorts illicites de l'Etat (Paris: Karthala), pp. 57-94.

Momani, B. (2013) In Egypt, 'Deep state' vs. 'Brotherhoodization' (Washington D.C: Brookings Institution) http://www.brookings.edu/research/opinions/2013/08/21 -egypt-brotherhood-momani (accessed on 26 April 2016).

Nachmani, A. (2003) Turkey: facing a new millennium (Manchester: Manchester University Press).

NATO (North Atlantic Treaty Organization) (1991) Le concept stratégique de l'Alliance, 8 November (Brussels: NATO), http://www.nato.int/cps/fr/natohq/official_texts _23847.htm (accessed on 24 May 2016).

Orun, İ. (1997) 'TSK'nın tarihine bir bakış', Savunma ve Havacılı, 5(7).

Özdemir, S. (2004) 'Başbakan’a broşür verdi, Pakistan’a iki Hücumbot sattı', Hürriyet, 3 février, http://www.hurriyet.com.tr/basbakana-brosur-verdi-pakistana-hucumbot -satti-200088 (accessed on 24 May 2016).

Polanyi K. (1957) The great transformation (Boston, MA: Beacon Press).

Radikal (2011) 'Iste Isadami Aziz Yildirim', 2 September, http://www.radikal.com.tr/eko nomi/iste-isadami-aziz-yildirim-1062085/ (accessed on 2 June 2016).

Rancière, J. (2004) Aux bords du politique, new edition [1990] (Paris: Folio).

Regnault, J.-M. (2003) 'France's Search for Nuclear Test Sites, 1957-1963', The Journal of Military History, 67(4), pp. 1223-1248, DOI: 10.1353/jmh.2003.0326.

Sabah (2011) 'Parola: Büyük ekonomi', 17 April, http://www.sabah.com.tr/ekonomi/ 2011/04/17/parola-buyuk-ekonomi (accessed on 2 June 2016).

Sabah (2010a) 'Özal'ın adayı Bitlis Paşa'ydı', Sabah, 15 October, http://www.sabah.com .tr/gundem/2010/10/15/genelkurmay_baskani_yapmak_istiyordu (accessed on 27 April 2016).

Şahin, H. (2002) Johnson Mektubu (Istanbul: Gendas).

Saymaz, I. and E. Çelikkan (2015) 'Turkey's top scientific body has no digital analysts left amid "political" layoffs', Hürriyet Daily News, 9 March, http://www.hurriyetdaily news.com/turkeys-top-scientific-body-has-no-digital-analysts-left-amid-political -layoffs.aspx? pageID $=238 \& n I D=79394 \& N e w s C a t I D=341$ (accessed on 27 April 2016).

Schmidt, D. (2014) 'Turquie: le syndrôme de Sèvres ou la guerre qui n'en finit pas', Politique étrangère, 79(1), DOI: 10.3917/pe.141.0199.

Sezgin, S. (2003) 'A Disaggregated Analysis of Defense Expenditure and Economic growth in Turkey and Greece', in Günlük-Senesen, G. and C. Kollias (eds.) Greece and Turkey in the 21st Century: Conflict or Cooperation a political economy perspective (New-York: Nova Sciences).

Söyler, M. (2015) The Turkish Deep State: State Consolidation, Civil-Military Relations and Democracy (London, New-York: Routledge).

Sözcü (2015) 'Alman mali “yerli uçak” geliyor', 28 May, http://www.sozcu.com.tr/2015/ gundem/alman-mali-yerli-ucak-geliyor-844206/ (accessed on 24 May 2015). 
SSM (Savunma Sanayi Mustesarligi) (2010) Historical Development (Ankara: Undersecretariat for Defence Industries) http://www.ssm.gov.tr/home/tdi/Sayfalar/histori cal.aspx (accessed on 22 December 2015).

Star (2015) 'Savunma devlerinin Katar çikarmasina BMC damgasini', 6 October. http:// haber.star.com.tr/ekonomi/savunma-devlerinin-katar-cikarmasina-bmc-damgasi/ haber-1061017 (accessed on 25 April 2016).

Taner, A. (2005) From Empire to Republic: Turkish Nationalism and the Armenian Genocide (London: Zed Books).

The Guardian (2016) 'Turkish journalists face secret trial for revealing arms deliveries to Syria', 25 March, http:/www.theguardian.com/world/2016/mar/25/turkish -journalists-can-dundar-erdem-gul-secret-trial-revealing-arms-deliveries-syria (accessed on 25 April 2016).

The Irish Times (1999) 'German cabinet faces dilemma over plan to sell tanks to Turkey', 29 October, http://www.irishtimes.com/news/german-cabinet-faces-dilemma -over-plan-to-sell-tanks-to-turkey-1.244166 (accessed on 26 April 2016).

The Korea Times (2015) 'Big-name arms broker arrested for alleged corruption', 11 March, http://www.koreatimes.co.kr/www/news/nation/2015/03/116_175076.html (accessed on 26 April 2016).

Timetürk (2012) 'Meger yüzde yüz Türk mali degilmis', 27 June.

Toyay, M. (2015) 'What does the Turkey-Qatar military deal mean for Arab conflicts?', Al Arabiya, 25 June, http://english.alarabiya.net/en/perspective/analysis/2015/06/25/ What-does-Turkey-Qatar-military-deal-mean-for-Arab-conflicts-.html (accessed on 23 May 2016).

Truman, H. (1947) 'Special Message to the Congress on Greece and Turkey: The Truman Doctrine', Truman Library Public Papers, 12 March, http://www.trumanlibrary.org/ publicpapers/index.php?pid=2189\&st=Turkey\&st1=Greece (accessed on 24 May 2016).

Tuğal, C. (2009) Passive Revolution: Absorbing the Islamic Challenge to Capitalism (Redwood City: Stanford University Press).

Turse, N. (2009) The Complex: How the Military Invades Our Everyday Lives (American Empire Project) (New York: Metropolitan).

Unsaldi, L. (2011) Le développement vu de Turquie (Paris: L'Harmattan).

Vaïsse, M. (1992) 'Le choix atomique de la France (1945-1958)', Vingtième Siècle. Revue d'histoire, 36, pp. 21-30, DOI: 10.3406/xxs.1992.2600.

Veyne P. (2014) Les Grecs ont-ils cru à leurs mythes? Essai sur l'imagination constituante (Paris: Seuil).

Ward, R. and Rustow, D. (eds.) (1965) Political Modernization in Japan and Turkey (Princeton: Princeton University Press).

Williamson, M. (2006) 'Ray Noorda. Pioneer of "co-opetition"', The Independent, 1 November., http://www.independent.co.uk/news/obituaries/ray-noorda-422415 .html 5 (accessed on 22 November 2016). 
Woertz, E, (2014) 'Egypt: return of deep state', Open Democracy, 20 January, https:// www.opendemocracy.net/arab-awakening/eckart-woertz/egypt-return-of-deep -state (accessed on 27 April 2016).

Wright Mills, C. (1956) The Power Elite (Oxford University Press).

Yankaya, D. (2015) 'Exposition industrielle, production de réseaux et construction d'imaginaires: la Foire internationale du Müsiad et les représentations de l'Etat turc', Etudes du Ceri, 215, pp. 1-36, http://www.sciencespo.fr/ceri/sites/sciencespo .fr.ceri/files/Etude_215.pdf (accessed on 24 May 2016).

Yankaya, D. (2014) 'International Business Forum: une tentative de régionalisation par la bourgeoisie islamique turque en "Afro-Eurasie"?', Anatolie, 5 , CNRS Editions.

Yankaya, D. (2012) 'Sermaye, burjuvazi, tahakkum', Birikim, 278-279, pp. 29-37.

Yentürk, N. (2014), 'Measuring Turkish Military expenditure', Sipri Insights on Peace and Security, 2014(1), http://books.sipri.org/files/insight/SIPRIInsight1401.pdf (accessed on 24 May 2016).

Yerasimos, S. (1994) 'Bilan Turquie 1993: une nouvelle dimension régionale' in L'état du monde (Paris: La Découverte). 